\title{
La escritora Ana de Zayas y el obispo poblano Manuel Fernández de Santa Cruz
}

\author{
Concepción Zayas \\ Doctoranda en Historia de América \\ Universidad de Sevilla
}

Estudio de caso sobre la relación entre el obispo de la diócesis angelopolitana, don Manuel Fernández de Santa Cruz, y doña Ana de Zayas, escritora que la Inquisición novohispana procesó por alumbrada de 1694 a 1700. Este trabajo analiza principalmente la intervención del prelado a favor de esta mujer, lo cual impidió que ella fuera condenada por el Santo Oficio de México. El artículo se basa en fuentes mexicanas y españolas.

\section{Introducción}

Nos acercamos a la peculiar relación que hubo entre la escritora, acusada de iluminista o alumbrada, doña Ana de Zayas y el obispo de Puebla don Manuel Fernández de Santa Cruz. Nuestro trabajo se centra principalmente en la intervención que hiciera el prelado a favor de la escritora en 1695 , lo cual prolongó los autos inquisitoriales y finalmente evitó que doña Ana fuera condenada por el Santo Tribunal.

Los protagonistas de esta historia pertenecen al reducido grupo de personas que en aquella Puebla de finales del siglo XVII podían acceder a la cultura que se adquiere en los libros. Empecemos por Ana de Zayas, quien había nacido hacia 1650 en esta ciudad y fue procesada por alumbrada de 1694 a 1700; su caso es particular, entre otras razones por tratarse de una mujer casada cuya sólida formación intelectual no se dio en ningún convento, situación poco frecuente para una época en la que la educación de las mujeres sólo podía darse bajo la regla conventual. Por razones aún desconocidas, su proceso criminal de fe quedó inconcluso; así lo hallamos tanto en el Archivo General de la Nación de México como en el Histórico Nacional de Madrid. ${ }^{1}$

Los pocos escritos de esta mujer que se han conservado en los documentos inquisitoriales son el único testimonio que hasta ahora hemos encontrado sobre el pensamiento de tan particular personaje femenino. Los

1 Archivo Histórico Nacional de Madrid (en adelante AHN), Inquisición, 1731, expediente 34; Archivo General de la Nación de México (en adelante AGN), Inquisición, vol. 692, expediente 2, fol. 290 . 
trabajos literarios de Ana de Zayas constituyeron la principal prueba de su delito. ${ }^{2}$ En ellos destaca la intencionalidad didáctica de la autora quien, por medio de su escritura, ofrecía con amenidad lecciones éticas que debían complementarse con la práctica de una vida virtuosa. Como se refiere en diversos pasajes del proceso, la vida y obra de Ana de Zayas resultaban un peligro para la República cristiana, principalmente por tratarse de una mujer que transgredía la ley de sometimiento con la que se intentaba sujetar a la población femenina. La escritora se rebeló contra la autoridad de su marido, contra sus confesores y trabajó por transmitirles a estos una manera distinta de vivir la religiosidad.

Nuestro otro protagonista, don Manuel Fernández de Santa Cruz, fue uno de los más destacados obispos de la Nueva España. Veló tenazmente por el progreso espiritual y terrenal de su diócesis desde el año que fue asignado a ocupar esta mitra, en 1676, hasta 1699, cuando murió. Fundó hospitales, colegios para teólogos y, sobre todo, se preocupó por crear instituciones que ampararan a las mujeres: escuelas, conventos y casas de recogidas. Fue nombrado dos veces, en 1680 y 1696, arzobispo y virrey ad interin de la Nueva España, puesto que rechazó en ambas ocasiones. Don Manuel compartía con Ana de Zayas el amor a las letras, fue escritor de lo divino - una triada de extensos volúmenes de teología lo demuestran- y también fue escritor de la cotidianeidad, como podemos comprobar en las cartas que dirigió a las diferentes religiosas que se acercaban a él pidiendo consejos espirituales.

Precisamente una carta que Fernández de Santa Cruz redactó a la más célebre monja novohispana, sor Juana Inés de la Cruz, ha convertido al obispo en una figura controvertida. ${ }^{3}$ No pretendemos sumarnos a la discusión que sobre el tema han mantenido los especialistas; nos limitaremos a ofrecer una información, hasta ahora inédita, basándonos en documentos que hemos encontrado en archivos históricos de México y España, pues nuestro estudio se centra en la relación que unió a este prelado con la escritora Ana de Zayas. El importante papel que Fernández de Santa Cruz

2 Ana de Zayas nunca fue llamada a declarar. En los autos inquisitoriales sus censores anotan: “...pondremos la conclusión de nuestro parecer acerca del juicio que hemos hecho de la escritora, pues para hacerlo, no tenemos otras premisas que sus escritos”. AHN, Inquisición, 1731, expediente 34, fol. 5. Proceso Inquisitorial contra Ana de Zayas.

3 Don Manuel Fernández de Santa Cruz fue quien publicó la crítica al jesuita portugués Antonio Vieyra, escrita por sor Juana Inés de la Cruz bajo el título de Crisis de un sermón. Dicho texto fue sacado a la luz por el obispo como Carta atenagórica, precedido de una epístola escrita por él mismo bajo el seudónimo de sor Filotea. 
desempeñó en la vida de otra fémina ilustrada, hasta ahora desconocida, nos ayudará a comprender con una variedad más amplia de matices las diferentes relaciones que las mujeres letradas podían llegar a mantener con los altos jerarcas eclesiásticos. Este artículo incide en la investigación que sobre la vida y obra de Ana de Zayas realizo para obtener el grado de doctor en Historia de América por la Universidad de Sevilla.

\section{Ana de Zayas: escritora y hereje}

Cuando en 1694 el Santo Tribunal novohispano abrió un proceso contra la escritora Ana de Zayas, acusándola de pertenecer a la secta de los herejes alumbrados, ella tenía aproximadamente 45 años y vivía en la Puebla de los Ángeles, lugar donde nació, hija de una pareja de españoles que se contaban entre los ciudadanos principales de esa ciudad. Desafortunadamente, para 1694 aquella desahogada vida familiar de la infancia había quedado muy atrás; los progenitores de doña Ana estaban muertos y ella se encontraba casada, desde hacía más de veinte años, con don Cristóbal Martínez de Cerdio, ${ }^{4}$ a quien nuestra autora le tenía puesta una demanda por malos tratos. ${ }^{5}$ La única hija que había sobrevivido del matrimonio se hallaba entonces recluída en un convento, situación favorable para que en 1695 la escritora obtuviera, como veremos más adelante, el permiso de separación marital gracias al apoyo del prelado Manuel Fernández de Santa Cruz.

Una vez conseguida la aprobación del obispado, doña Ana abandonó a su marido y se recluyó en una casa de recogidas, donde continuó su labor literaria. Según los testimonios, esta mujer pasaba la mayor parte del día escribiendo, llevando una vida sin tacha. Sus salidas a la calle tenían como principal destino las iglesias; allí, dialogaba con los clérigos y les entregaba unos papeles, redactados por ella misma, donde habló de ideas y visiones relacionadas con nuevas formas de experimentar la espiritualidad. Dichos textos fueron el punto clave para que a Ana de Zayas se le denunciara por alumbrada en noviembre de 1694. La acusó uno de sus confeso-

4 Hijo de un capitán de marina, don Cristóbal Martínez de Cerdio había llegado a la Nueva España cuatro años antes de contraer nupcias con Ana de Zayas.

5 Como sabemos, en la Nueva España hubo un alto índice de mujeres maltratadas por sus consortes y el caso de nuestra escritora se suma a esta generalidad. En el proceso existen muchas referencias sobre la mala relación de Ana de Zayas con su marido, para ejemplo citamos un comentario de ella: "...me he de salir huyendo por donde Dios me guiare, aunque sea el infierno si allá me llevare". AHN, Inquisición, 1731, expediente 34, fol. 69 v. Proceso Inquisitorial contra Ana de Zayas. 
res: "por hallarse en sus hechos, dichos y escritos, cosas y proposiciones temerarias, escandalosas, mal sonantes y sospechosas". ${ }^{6}$

Hagamos un breve paréntesis para hablar de los herejes ${ }^{7}$ alumbrados o iluministas, secta radical de carácter místico que originalmente surgió en Guadalajara, España, en las primeras décadas del siglo XVI; ${ }^{8}$ fueron uno de los grupos que brotaron dentro de la gran conmoción religiosa que sacudía la Europa de entonces. Los alumbrados se nutrieron de la mística tradicional de occidente y el neoplatonismo gnóstico reavivado por el Renacimiento, y su idea central era concebir a la fe como amor o experiencia. ${ }^{9}$ Revisemos a continuación la definición que sobre los alumbrados nos ofrece el denunciante de Ana de Zayas:

"Aquellos que habiendo alcanzado a su parecer una gran quietud interior del alma, se tienen por hombres contemplativos; y así sólo atienden a las ilustraciones interiores sin atender ni hacer cuenta de los preceptos y mandatos de la iglesia; ni sujeción ninguna a consejos de doctos, ni dirección de prelados aunque sea el sumo pontífice". ${ }^{10}$

Como vemos, los términos alumbrado o iluminado, a la par de calvinista o jansenista, fueron empleados como denominaciones que, de manera general, señalaban a cualquiera que intentara salir del control de la Iglesia. El origen del iluminismo mexicano se remonta al siglo XVI y tuvo como raíz al anacoreta Gregorio López ${ }^{11}$ (Madrid, 1524 ${ }^{12}$ - México, 1596).

6 Ibídem, fol. 110.

7 Sabemos que en el siglo XVII hereje era aquél que pertenecía a una secta apartada de la Iglesia y perseveraba en sus opiniones contra el canon católico. "Apud nos catholicos, haeresis est dogma contra id quod Ecclesia Catholica Romana docet et tenet. Las proposiciones que se condenan y califican son en cinco maneras: temerarias, escandalosas, erróneas, suspectas, heréticas. Y en una pueden concurrir todas". Covarrubias, Sebastián: Tesoro de la lengua Castellana o española. Barcelona, 1943, pág. 530 .

8 Ver Bataillon, Marcel: Erasmo y España. México, 1966, pág. 167. También en Márquez, Antonio: Los alumbrados. Orígenes y filosofía. Madrid, 1980, pág. 153.

9 Márquez, Los alumbrados. ..., pág. 222.

10 AHN, Inquisición, 1731, expediente 34, fol. 107. Proceso Inquisitorial contra Ana de Zayas.

11 Con intención o sin ella, lo cierto es que Gregorio López se convirtió en el origen de la secta alumbrada en México. "En los procesos instruídos por el Tribunal novohispano de 1595 a 1600, se nombra a Gregorio López en diversas ocasiones, como si hubiera sido el origen de la secta de los alumbrados de la Nueva España". Huerga, Álvaro: Historia de los alumbrados. Los Alumbrados de Hispanoamérica (1570-1605). Madrid, 1980, pág. 516.

12 Poco se sabe de cierto sobre el pasado que tuvo López antes de su llegada a América. Su hagiógrafo, Francisco Losa, ubica su nacimiento en Madrid, pero también se ha dicho que pudo haber nacido en Portugal. Pedro Lobo Correa, traductor al portugués de la Vida de Gregorio Lopes, composta en castelhano pele Licenciado Francisco de Losa, acrecentado o primeiro e ultimo capítulo, Lisboa, 1665, reivindica para la tierra lusitana el nacimiento del primer anacoreta de Indias. La misma postura ha tomado Mario Martins, Gregório Lópes, o anacoreta das Indias, en "Brotéria" 36, 1943, págs. $365-$ 376. Citadas ambas obras por Huerga, Historia ..., págs. 514 y 515. 
Aunque la vida de este personaje estuvo entregada sobre todo a la contemplación y la lectura, ${ }^{13}$ el ermitaño también se encargó de guiar con sus luces a un pequeño grupo de seguidores, personas de la capital novohispana y de Puebla, que lo visitaban frecuentemente buscando sus enseñanzas. Años después de la muerte del anacoreta, Felipe II promovió su canonización. ${ }^{14}$ Sin embargo, los discípulos de Gregorio López no corrieron la misma suerte $y$, acusados de iluministas, fueron perseguidos por el Santo Oficio durante la última década del siglo XVI. Así nació el primer foco de tal herejía en la Nueva España. Como había ocurrido en la Península, el movimiento de México tuvo entre sus protagonistas a varias mujeres. ${ }^{15}$

Por el momento es difícil precisar hasta qué punto nuestra autora estuvo ligada al grupo de los primeros alumbrados de la Nueva España; un siglo exacto la separa de esta célula embrionaria y durante cien años el movimiento debió sufrir transformaciones, sobre todo después de que la Inquisición encarcelara a sus principales promotores. A reserva de que encontremos evidencias contrarias, a estas alturas del trabajo podemos afirmar que el caso que estudiamos es producto de un nuevo cuerpo heterodoxo, con sus propias particularidades y diferencias respecto a los orígenes del iluminismo mexicano, pero que retomó de éste, entre otras, la idea de una espiritualidad de experiencia o práctica, es decir, una religiosidad que se tradujera en obras virtuosas, punto esencial en el que insiste doña Ana a través de varios de sus escritos, como en su Juego de maroma o Danza moral:

"Predicar virtudes, y ejercitar vicios, es haber perdido el juicio, porque es imposible que ninguno haga caso de la doctrina elocuente a vista de la vida licenciosa (...) De la boca del loco es mal recibida la palabra sentenciosa, porque todos miran al dechado de las obras, más que al primor de las palabras". ${ }^{16}$

Como Catalina de Siena, a quien Ana de Zayas llamaba su maestra, ${ }^{17}$ nuestra escritora también aseguraba tener visiones que, a su manera, tradujo a palabras escritas. Aparentemente el caso de doña Ana podría incluirse

13 Fue dueño de una pequeña biblioteca, dominaba el latín y escribió varios volúmenes sobre materias tan diversas como un tratado de medicina herbolaria, una interpretación del Apocalipsis y apuntes sobre temas relacionados con la cuenta del tiempo (calendarios y cronologías).

14 En el año de 1620. Huerga, Historia ..., pág. 529.

15 La monja Agustina de Santa Clara, pilar femenino del iluminismo poblano, es prueba de ello. AGN, Inquisición, 210, expediente 2, fol. 31 r. Citado por Huerga, Historia ..., pág. 570. Esta religiosa no fue la única; los procesos inquisitoriales guardan una rica información sobre la gran participación femenina en los movimientos alumbrados de América y España

16 AHN, Inquisición, 1731, expediente 34, fol. 5 v. Proceso Inquisitorial contra Ana de Zayas.

17 Ibídem, fol. $11 \mathrm{v}$. 
en el de muchas de sus coetáneas, beatas arrobadas por el éxtasis místico; ${ }^{18}$ sin embargo, la formación intelectual de nuestra autora la diferencia del común de visionarias de su contexto. ${ }^{19}$ Además de las experiencias ligadas a lo inexplicable de lo divino, Ana de Zayas manejaba el conocimiento letrado que se adquiría leyendo. En una discusión entablada por la autora con el fraile que la denunció, ella misma explica la dualidad, intelectual e infusa, de sus textos:

“Cuándo he dicho yo que esto es adquisito? Lo que digo es que es infuso, y que a esto puede ayudar la lección de libros, no se niegue; pero eso es a quien se le queda algo en la memoria, pero a mí no se me queda. Lo que yo le dije a vuestra ilustrísima fue que he leído mucho, pero no digo, ni diré, que de aquí escribo". ${ }^{20}$

Sobre el mismo tema, en otro fragmento del proceso, doña Ana explica:

"Lo que digo es que Dios me dice escribe; y con sólo decir esto se infunde lo que he de decir. Otras veces me da la inteligencia, el asunto o el sentido en que he de hablar, y con cualquier cosa de estas se me infunde todo sin trabajo mío". ${ }^{21}$

Conocemos muy poco sobre cuáles habrán sido las fuentes de información de Ana de Zayas y la forma como accedió a ellas. Las mujeres de entonces estudiaban durante sus primeros años en clases particulares con la "amiga" (instructora que de forma casera educaba en las primeras letras), en colegios para niñas, conventos o beaterios; en ellos recibían lecciones de música, religión y labores femeninas. Las jóvenes que tenían mayores inquietudes, y fortuna, continuaban estudiando de forma particular, generalmente para aprender gramática latina y castellana. Aspirar a acceder a un tipo de estudios más sistematizados tenía un solo camino: el convento.

Esa ha sido la idea que hasta ahora hemos manejado y el ejemplo más conocido de tal situación es el de sor Juana Inés de la Cruz. Sin embargo, ¿por qué caminos anduvo doña Ana para conseguir la sólida cultura letrada que tenía? Podríamos aventurarnos a preguntar, ¿y si aparte de la educación reglada femenina, hubiera existido alguna formación especial, una

18 Si se corría con suerte y la aprobación inquisitorial, el misticismo era una de las pocas fuentes de prestigio público y autoridad a la que las mujeres de entonces tenían acceso; quizá por eso fueron muchas las que echaron mano de este recurso. Ver Surtz, Ronald E.: La guitarra de Dios. Madrid, Anaya \& Mario Muchnik, 1997, pág. 24.

19 O por lo menos de aquéllas que no seguían la educación reglada de los conventos.

20 AHN, Inquisición, 1731, expediente 34, fol. 31. Proceso Inquisitorial contra Ana de Zayas.

21 Ibídem, fol. 32. 
tertulia importante que legalmente no se conociera pero que funcionara como centro de aprendizaje? Dejemos la pregunta abierta a próximas investigaciones y pasemos ahora a revisar algunos puntos sobre el ejercicio de la escritura en aquella época.

En el siglo XVII, la escritura femenina ${ }^{22}$ requirió siempre de la aprobación de un superior eclesiástico; ${ }^{23}$ tanto en el caso de las monjas encargadas de relatar ejemplarmente hechos relacionados con la vida de sus conventos o de sus compañeras religiosas, como en todas aquellas seglares que, aunque en menor medida, tomaban la pluma por la necesidad de expresar sus experiencias místicas. ${ }^{24}$ En todos los casos, las autoras debían tener detrás una figura masculina eclesiástica que las respaldara, ¿hasta qué punto llegaba la relación entre las escritoras y los hombres que las legitimaban?; ¿existió algún tipo de libertad subterránea entre ellas y su escritura? En el caso que estudiamos es difícil marcar una frontera definitiva; no obstante, si nos guiamos por la información de los autos inquisitoriales, podemos afirmar que Ana de Zayas se vio obligada, como todas sus coetáneas, a buscar la legitimidad de un confesor, pero finalmente terminó obedeciendo sólo a su propio espíritu.

Doña Ana pertenece a esa minoría, hasta ahora poco estudiada, de mujeres seglares que en el siglo XVII novohispano tuvieron la posibilidad de escribir. El haber estado casada, y por tanto, fuera del cobijo conventual, sitúa a nuestra autora en un lugar de pros y contras que la diferencian notablemente de los casos de monjas escritoras ${ }^{25}$ dadas a conocer en diversos estudios sobre el tema. Como otras mujeres acusadas de alumbradismo, la actitud de Ana de Zayas violaba uno de los grandes principios de autoridad al no someterse a sus confesores e intentar adoctrinarlos:

22 Muriel, Josefina: Cultura femenina novohispana. México, 1994. pág. 177.

23 Glantz, Margo: Sor Juana Inés de la Cruz, ¿hagiografía o autobiografía? México, 1995,

24 Este procedimiento se había seguido desde España, donde entre 1500 y 1700 hubo centenares de monjas escritoras; las visionarias estaban obligadas a escribir sus experiencias, de forma que la Inquisición les otorgara o negara la legitimación. Surtz, La guitarra ..., pág. 23.

25 Dentro del contexto novohispano hubo otras famosas alumbradas escritoras. El caso más renombrado en el siglo XVII fue Josefa Romero o Josefa de San Luis Beltrán, quien hacia 1648 dictó sus revelaciones al padre Bruñón de Vértiz, su seguidor. Jiménez Rueda, Julio: Herejías y supersticiones en la Nueva España. México, 1946. Este caso es harto distinto al de Ana de Zayas, sin embargo lo citamos como una referencia de alumbradismo y escritura en otra mujer del siglo XVII. En Europa existieron notables casos de mujeres seglares que tomaron la pluma para difundir, como Ana de Zayas, ideas que pretendían renovar las formas de vivir la espiritualidad. Un caso coetáneo a nuestra alumbrada es el de Madame Guyon en Francia. 


\begin{abstract}
"Reconociendo ella que los confesores no apoyan sus cosas, y (ni) aplauden sus revelaciones, visiones, ni aprueban su espíritu, se vuelve una víbora y serpiente, los injuria y los desprecia y los deja y huye de ellos. Y este atrevido arrojo dice que Dios se lo manda". ${ }^{26}$
\end{abstract}

Acusaciones como éstas son las que se reiteran en el proceso:

"Presume de enseñar a sus confesores en lugar de recibir con resignación sus direcciones y, además, se gobierna con su propio espíritu". ${ }^{27}$

Ana de Zayas dio prioridad a su labor didáctica porque, como ella misma afirmaba, Dios la había creado para fines muy concretos, entre ellos ser escritora y maestra de espíritu. El valor que la autora concedió a su escritura como medio para divulgar su propuesta espiritual coincide con el caso de los primeros alumbrados de España y México. Doña Ana tuvo otros importantes puntos de conexión con ciertos rasgos esenciales de los orígenes del alumbradismo, como una favorable inclinación al conocimiento letrado y el emplear la escritura, además de medio de divulgación, como un testimonio que debía permanecer a través del tiempo. Para ejemplo contamos con el caso de un personaje relevante para el alumbradismo mexicano, ${ }^{28}$ quien pidió plasmar en papel sus memorias antes de ser encarcelado. Sobre el mismo tema tenemos un fragmento de la obra de Ana de Zayas en el que ella pide que sus escritos sean conservados: "por amor de Dios pido que no se pierdan los papeles, que aunque fueran disparates...". ${ }^{29}$

Nuestra autora unió a su formación intelectual la ciencia infusa de los visionarios y ambos mundos quedaron plasmados en la parte de su obra (epigramas, poemas alegóricos, epístolas y textos autobiográficos) que se preserva en los documentos inquisitoriales. Ana de Zayas fue una mujer heterodoxa no sólo por lo que dijo o escribió, sino también por lo que hizo: atreverse a promover abiertamente entre los miembros del clero una valio-

26 AHN, Inquisición, 1731, expediente 34, fol. 41. Proceso Inquisitorial contra Ana de Zayas.

27 El dictamen es del calificador del Santo Oficio, Agustín Dorantes, el mismo que se encarga de censurar el panegírico a sor Juana Inés de la Cruz que escribiera Xavier Palavicino, a quien Dorantes acusa de "Complacer el genio de una mujer introducida a teóloga y escriturista." Véase Poot Herrera, Sara: Las cartas de sor Juana: públicas y privadas. En Margo Glantz, comp.: Sor Juana Inés y sus contemporáneos. México, 1998, págs. 291-317, pág. 313.

28 Nos referimos a Juan Plata, padre capellán de las monjas del convento de Santa Catalina de Siena de Puebla, amigo de la religiosa poblana, Agustina de Santa Clara, de quien ya hemos hablado. Antes de ser apresado, Plata anduvo entre México y Puebla, de casa en casa, transmitiendo el mensaje de una nueva religiosidad. Huerga, Historia ..., pág. 571.

29 AHN, Inquisición, 1731, expediente 34, fol. 5 v. Proceso Inquisitorial contra Ana de Zayas. 
sa concepción y práctica de la religiosidad. Entregarse a esta labor pudo costarle duros castigos como el ser condenada a las cárceles secretas del Santo Oficio, lo cual no ocurrió gracias a la intervención que el obispo de Puebla hiciera a favor de esta mujer.

\section{Manuel Fernández de Santa Cruz: corazón en el convento}

Este eclesiástico llegó a México en 1673. Tenía entonces 36 años y había conseguido ya los más altos títulos académicos de las mejores universidades de su España natal: licenciado por la Universidad de Salamanca, doctor por la de Valladolid, así como el haber ejercido de canónigo magistral en Segovia. La razón por la que el joven Santa Cruz cruzó el Atlántico fue su nombramiento como obispo de Chiapas, puesto que nunca ocupó porque finalmente se le designó a la mitra de Guadalajara (México). A punto de cumplir cuarenta años, en 1676, un nuevo cambio lo destinó a la Puebla de los Ángeles, donde, literalmente, dejaría su corazón.

Cuando Manuel Fernández de Santa Cruz llegó a Ángeles — como se denominaba comúnmente a la Puebla según el nombre que Carlos V le había dado- se cumplían exactamente cien años desde que este lugar recibiera de Felipe II la denominación de muy noble y leal ciudad. ${ }^{30}$ El poder se movía por el juego de sus opuestos: jerarquía eclesiástica y autoridades civiles, iglesia secular y órdenes religiosas. A la problemática interna de Puebla se agregaban sus conflictos con la capital: ambas eran las ciudades más importantes de la Nueva España, separadas por dos imponentes volcanes que, al parecer, resultaron pequeños para evitar los muchos altercados.

El universo fantástico que, de manera general, empapó a la cultura novohispana se agudizaba en ciudades criollas como Ángeles, donde, antes y después del siglo XVII, siempre existió una especial tendencia a que sus habitantes se recrearan con apariciones divinas o demoniacas. En este contexto era natural ver a San Pedro echando sus redes en las callejuelas inundadas por las torrenciales lluvias de julio, o que San Miguel Arcángel se comunicara con un indio llamado Diego Lázaro. ${ }^{31}$ Incluso, la ciudad tenía sus santas propias, como la afamada beata Catalina de San Juan. En esta Puebla de miserias y prodigios, Manuel Fernández de Santa Cruz vería cumplidos sus más queridos sueños de buen pastor: fundó hospitales, edificó el colegio

30 Carrión, Antonio: Historia de la ciudad de Puebla. Puebla, 1896, pág. 41.

31 AGI, México, 346, fol. 1173 v. 
de San Pablo para teólogos pasantes y mantuvo diversas casas de amparo para mujeres. La satisfacción que sentía de sus labores como obispo se traduce en las siguientes palabras escritas por el propio prelado:

"Porque con la grande experiencia y conocimiento que tengo adquirido en la continua asistencia de casi dieciseis años que ha que sirvo a esta catedral, estoy tan satisfecho del lleno y puntualidad de sus obligaciones que me atreveré a afirmar, sin recelo alguno, que ninguna de las mayores y más acreditadas iglesias de la Europa excede a ésta, y que en este reyno, y otros, es edificativo modelo y sobresaliente y venerable ejemplar de las más lucidas y aventajadas catedrales". ${ }^{32}$

El buen camino por el que andaban las muchas empresas de don Manuel Fernández de Santa Cruz en la diócesis poblana fue probablemente un motivo de peso para que el prelado no aceptara convertirse en arzobispo de México en 1680, pero detengámonos brevemente en este pasaje para aclarar algunos puntos. En Madrid, el 6 de junio de 1680, le fue concedida a fray Payo de Rivera, entonces arzobispo de México y virrey ad interin, ${ }^{33}$ la licencia para renunciar a su puesto. Ocho días después, en una consulta del Consejo de Indias, la Cámara propuso en primer lugar a Fernández de Santa Cruz en la terna de posibles candidatos a ocupar la mitra metropolitana; en la minuta del documento podemos leer la respuesta de Carlos II: "Nombro al obispo de la Puebla de los Ángeles. Y en falta suya al de Michoacán". ${ }^{34}$

La cámara había elegido con justicia a Santa Cruz: "así por su virtud y la satisfacción que se tiene de su persona, como por ser el inmediato prelado a quien regularmente tocare hacerlo". ${ }^{35}$ Sin embargo, al obispo de Puebla no le tentaba abandonar su diócesis y así lo había insinuado en 1679 , meses antes de ser nombrado arzobispo, por medio de un sobrino suyo que había llegado a la Corte. ${ }^{36} \mathrm{La}$ insinuación fue confirmada por don Manuel cuando declinó el nombramiento de arzobispo y dejó el camino libre para que Francisco Aguiar y Seijas, entonces obispo de Michoacán, ocupara la mitra metropolitana.

32 Ibídem, fol. 1176 y 1177. Fechado el 27 de julio de 1692.

33 AGI, Indiferente General, 3017.

34 Ibídem.

35 Ibídem.

36 “... pero teniendo presente la Cámara el riesgo que puede haber en que no acepte (Fernández de Santa Cruz) el arzobispado, como ha sucedido con otros antecesores suyos, y como lo ha insinuado un sobrino suyo que se halla en la Corte y vino de aquella diócesis en la última flota que llegó a estos reinos (...) el año pasado de 1679”. Ibídem. 
El hecho es importante para esclarecer la imprecisa opinión que Octavio Paz sostiene en Las trampas de la fe donde, según la interpretación de dicho autor, el prelado de Puebla competía con Aguiar y Seijas por el arzobispado. ${ }^{37} \mathrm{Hemos}$ visto que no hubo tal rivalidad, o por lo menos no por parte de Santa Cruz, quien manifestó a través del sobrino su nulo interés por acceder a la mitra metropolitana desde 1679 , antes de que se la ofrecieran en 1680. Con lo anterior podemos ver que tampoco hubo lo que el autor de Las Trampas de la fe llama "una poderosa interferencia", ${ }^{38}$ que hiciera cambiar la decisión de Madrid a favor del entonces obispo de Michoacán; sobre el mismo tema, carece de fundamento la frase siguiente: "la elección del arzobispo se hizo de una manera misteriosa...", ${ }^{39}$ ya que, como vemos, Paz llama "misteriosa" a una rutinaria consulta del Consejo de Indias con su respectiva resolución real.

El Consejo normalmente proponía a varios candidatos para puestos de tanta importancia y, en la ocasión que nos ocupa, existía además, como dijimos, el antecedente del sobrino del obispo de Puebla, quien, llegado a la corte, insinuó que su tío no estaba dispuesto a ocupar la sede metropolitana. Es importante aclarar este detalle porque una de las tesis principales que maneja Octavio Paz en su libro sobre sor Juana Inés de la Cruz es justamente que esta mujer fue víctima de las rivalidades entre los dos grandes jerarcas eclesiásticos, Francisco Aguiar y Seijas y Manuel Fernández de Santa Cruz. Como ya señalamos, el autor de Las trampas de la fe funda dicha tesis en la imprecisa idea de que el obispo de Puebla mantenía una especial relación de conflicto con el arzobispo por haberle éste arrebatado la oportunidad de acceder a la mitra metropolitana en 1680. Lo cual, según hemos visto, es falso. Esto no significa que entre ambos prelados no haya habido serias diferencias de perspectiva y concepción sobre la manera de administrar material y espiritualmente sus respectivas diócesis, pero tales diferencias no se debían a las razones que Octavio Paz ha propuesto.

Volvamos a centrarnos en Fernández de Santa Cruz. Dentro de un relicario de cristal y metales preciosos, resguardado por los gruesos muros del coro alto del convento de Santa Mónica, se conserva hasta hoy el corazón de don Manuel, tal como lo ordenara en su testamento: su corazón debía permanecer muerto donde había estado en vida. El sueño personal más importante del prelado fue esta fundación que se había echado a andar en

37 Paz, Octavio: Las trampas de la fe. México, 1990, pág. 525.

38 Ibídem, pág. 526.

39 Ibídem. 
1683 como Casa y Colegio de Santa María Magdalena, ${ }^{40}$ y que tres años después se convertiría en el convento de Santa Mónica, bajo la regla de agustinas recoletas.

Además de los ambiciosos proyectos del prelado, como fueron la fundación de hospitales, conventos y colegios, los pequeños trabajos cotidianos de este obispo reflejan a un hombre entregado a su misión: conseguir el progreso espiritual y material de su diócesis. Para ello, Fernández de Santa Cruz puso especial atención en ver con sus propios ojos las necesidades de sus feligreses y, coherente con sus principios, emprendía largos viajes que abarcaban las sierras y las costas:

“... he conseguido el visitar tres y cuatro veces la mayor parte del obispado, y enteramente le he recorrido dos veces llegando a pueblos, curatos y doctrinas en que jamás habían visto ni el suyo, ni ajeno prelado. Caminando más de seis mil leguas, casi lo más a caballo, por ser tan dilatados sus términos, y tener de norte a sur doscientas leguas de longitud de fragosos y peligrosos caminos por sus frecuentes precipicios destemplados y casi intolerables temperamentos". ${ }^{41}$

Cuando en junio de 1693 sus achaques le impedían visitar la sierra totonaca, solicitó ser relevado de su cargo por hallarse muy enfermo y no poder cumplir con la principal obligación de su ministerio que, según don Manuel, consistía en que el pastor reconociera personalmente a sus ovejas. ${ }^{42}$ Las incursiones que el obispo hizo a los sitios más apartados de la diócesis le permitieron ser muy exigente con los miembros del clero secular y regular; durante sus visitas pastorales comprobó el desorden que reinaba y criticó las malas costumbres de los ministros quienes, además de deshonestos, eran iletrados, según opinión de Fernández de Santa Cruz. ${ }^{43}$ Tuvo muchos problemas con la cuestión de las doctrinas, especialmente con los franciscanos:

"La materia más grave de este obispado y su clero (...) es el pleito de las doctrinas que sirve, de que ha casi cuarenta y cinco años que está en legítima posesión habiendo sido removida de ellas la seráfica religión de san Francisco en conformidad de lo dispuesto por los sagrados cánones y concilios y repetidas reales cédulas que resistió y contravino obstinadamente la religión por muchos años...". ${ }^{44}$

40 Casa fundada con los bienes del canónigo Francisco Reynoso. AGI, México, 346, fol. 958.

41 Ibídem, fol. 1273. Fechado en 25 de junio de 1683.

42 Ibídem.

43 Este comentario lo hizo contra algunos miembros del Santo Oficio, con quienes el prelado mantuvo relaciones tirantes, como veremos más adelante. Ibídem, fols. 1255-1256. Fechado en junio de 1693.

44 Ibídem, fol. 975. Puebla, 9 de octubre de 1685. 
Con las autoridades civiles también mantuvo una actitud crítica y más de una vez denunció los abusos cometidos por los alcaldes; la precisión de su prosa da una idea clara del desamparo y la injusticia que existió en aquellas provincias, sobre todo en las zonas indígenas:

"Por los procedimientos de estos alcaldes mayores podrán respectivamente regularse lo de los demás, porque todos siguen una misma senda en que el desorden es más crecido mientras mayor y más acomodado es el oficio; porque todos comercian y contratan; y solamente dejan de hacerlo los faltos de caudal, que en cierto modo suelen ser los peores, porque la pobreza los obliga a incurrir en increíbles indecencias". ${ }^{45}$

Otro tema que le preocupó constantemente al obispo fue la formación intelectual de los sacerdotes. A los ojos de don Manuel la ignorancia de los clérigos podía ser causa de graves consecuencias, como puede verse en el siguiente fragmento de la correspondencia del prelado, donde además de quejarse por la falta de sacerdotes que debían residir en las doctrinas, acusa la poca ilustración de los religiosos: "por ausencia de curas propios y por quedar en su lugar coadjutores que regularmente son personas ignorantes e iletradas, sucedían muertes de indios". ${ }^{46}$

Manuel Fernández de Santa Cruz fue un amante del conocimiento letrado. En una carta que escribe a su confesor explica que, después de acabadas sus labores, a las nueve de la noche: "desde esta hora a las diez, o rezo, o estudio; en esto hay infinitas faltas, porque me entrego con ansia, y nimiedad a los libros; conservando poca o ninguna preferencia de Dios". ${ }^{47}$

\section{La escritora, el obispo y la Inquisición}

¿Cuándo se conocieron Ana de Zayas y Manuel Fernández de Santa Cruz? El proceso inquisitorial ofrece la primera referencia en septiembre de 1693, aunque es muy probable que su relación hubiera sido anterior. Para tener una idea de cuál era el contexto en el que se movía por entonces el obispo, señalaremos algunos detalles importantes como que el 25 de junio de ese año Santa Cruz había solicitado por primera vez le fuera permitido renunciar a su cargo: "Por la quiebra de salud, e imposibilidad de visitar la

45 Ibídem, fol. 26. Fechado el 22 de febrero de 1681.

46 Ibídem, fol. 980.

47 Torres, Miguel: Dechado de príncipes eclesiásticos que dibujó con su ejemplar, virtuosa, y ajustada vida el Ilustrísimo y excelentísimo señor don Manuel Fernández de Santa Cruz y Sahagún. Puebla, 1721, pág. 397. 
mayor parte del obispado" ${ }^{48}$ Ese mismo 1693, don Manuel tuvo una grave diferencia con el virrey Conde de Galve, centro del famoso motín del año anterior, por no acceder el prelado a abastecer con las reservas de granos de los diezmos las carencias que había en las trojes de la capital. Dicho altercado puso de manifiesto, una vez más, la tenacidad con que este obispo defendía sus causas; el asunto terminó en concordia para ambas partes, pero fue el virrey quien tuvo que ceder y respetar la decisión del prelado. ${ }^{49}$

Una vez señalados algunos puntos sobre el contexto de Manuel Fernández de Santa Cruz, regresemos al hecho que lo une con Ana de Zayas; en septiembre de 1693 el prelado redactó las siguientes frases dirigidas a doña Ana: "Hija, he visto tus papeles, y en todos conozco estás poco sana de la cabeza, el remedio de no empeorar es no escribir, y no escribir hasta que yo te avise". ${ }^{50}$ La prohibición que le hacía a la escritora tenía detrás una razón de peso, pues estas palabras fueron escritas por don Manuel cuando éste ya tenía conocimiento de que el fraile carmelita Alonso de Cristo elaboraba la denuncia donde acusaba a la autora de pertenecer a la secta de los herejes alumbrados.

Dicha acusación fue entregada al Santo Oficio de Puebla el 15 de octubre de aquel 1693. En ella, fray Alonso de Cristo recurre a una larga argumentación escolástica, propia de la época; además de ampararse en los respectivos puntos teológicos, el carmelita reforzaba su denuncia con fragmentos de la carta que hemos visto anteriormente, donde el obispo manda a la acusada dejar de escribir en bien de su salud mental. Lo que leeremos a continuación es el comentario que el denunciante fray Alonso hace sobre dicha epístola, en la que, refiriéndose a Ana de Zayas, dice:

"Y qué más claros desengaños para dejar sus ilusiones y quimeras, y para rendirse a obedecer en todo a su pastor y prelado (...) es mi parecer que las visiones, y hablas, y revelaciones y profecías de esta persona no son seguras ni verdaderas, que no es bueno, ni de Dios, sino ilusión de espíritu; y que engañada del demonio la va este enemigo precipitando y llevando a mucho mal y desdicha. Si con tiempo no toma y sigue los consejos buenos y santos de su pastor y prelado". ${ }^{51}$

Sin embargo, contra lo que el carmelita esperaba, hacer referencia a la censura que Fernández de Santa Cruz hiciera a la escritora ayudó a que los

48 AGI, México, 346, fol. 1273.

49 Torres, Dechado ..., págs. 270 y 271.

50 AHN, Inquisición, 1731, expediente 34, fols. 66 y 66 v. Proceso Inquisitorial contra Ana de Zayas.

51 Ibídem, fol. $100 \mathrm{v}$. 
inquisidores no dieran seguimiento a la denuncia, por no hallar delito que perseguir en una mujer que, según el obispo, estaba dañada de su imaginación. El Santo oficio no procesaba a los locos; así, don Manuel protegió a Ana de Zayas en esta primera acusación, como podemos comprobar en la respuesta a Alonso de Cristo dada por los miembros del Tribunal, fechada el 24 de enero de 1694:

“... reconociendo por su discurso que la lastimosa mujer a quien tira a desengañar ha pasado por la noticia, examen y comprensión del ilustrísimo señor obispo de la Puebla, quien como tan versado en esta dificultísima teología explica su dictamen y parecer de que está dañada de su imaginación. Nos ha parecido conformarnos o sujetarnos a su claro conocimiento, y calificar por loca, bachillera y ridícula (...) Porque de no ser así, sería ilusa, blasfema, herética, y hubiera corrido toda la selva de la secta de los alumbrados: digna, en fin, de que el Santo Oficio la reconociese y enmendase. Pero siendo (como su ilustrísima dice) delirios de su lesa imaginación, será conveniente que a quien pertenece enmendarla, la disuada, corrija y ponga (si es capaz) en camino de salvación, antes que su capricho y temeridad la precipite a la desesperación". ${ }^{52}$

El denunciante Alonso de Cristo quedó inconforme con que el Santo Tribunal no abriera un proceso contra doña Ana, así que entre enero y agosto de 1694 volvió a enviar una larga perorata dirigida a los calificadores. En esta ocasión, fray Alonso iba armado con los autores más graves de la medicina: Galeno, Hipócrates, Luis Lobera de Ávila ... para demostrar que en Ana de Zayas no había "las señales y necesarios efectos que comúnmente acompañan a las diferentes enfermedades que perjudican, disminuyen y depravan la razón y el juicio". ${ }^{33}$

Fray Alonso aclara a los inquisidores que refirió la carta que el señor obispo envió a doña Ana mandándola dejar de escribir con el fin de probar, no la demencia de la acusada, sino que sus revelaciones eran falsas y sospechosas de alumbradismo. Según el carmelita, el prelado no consideraba a Ana de Zayas una loca, de ser así la habría mandado encerrar en lugar de darle sabios consejos, ${ }^{54}$ lo cual contradecía la opinión que el propio obispo daba explícitamente en la epístola a la que nos hemos referido, donde don Manuel, sin rodeos, le dice a la escritora que está "poco sana de la cabeza".

Alonso de Cristo entregó a Fernández de Santa Cruz una copia de esta segunda apelación al Santo Tribunal, pidiéndole al prelado consejo para la

52 Ibídem, fol. 110.

53 Ibídem, fol. 111.

54 Ibídem, fol. 124. 
resolución del caso. En respuesta, don Manuel mandó por decreto, el 14 de agosto de 1694, que un par de médicos dieran su parecer sobre la salud mental de la acusada:

"Por cuanto estoy informado de que los ilustres doctores Baez y Cruz han curado a doña Ana de Zayas, en una ocasión en que estuvo furiosa, se han de servir en decir su parecer en orden a la especie de locura que padeció, y si hoy padece algunos lucidos o semejante pasión". ${ }^{55}$

Los médicos informaron que, si bien la acusada, aproximadamente tres años antes, había estado enferma de "furioso delirio con audacia", vulgarmente loca, en la actualidad se hallaba perfectamente sana. ${ }^{56}$ Sabemos por fray Alonso que, después de conocer el parecer de los médicos, el prelado mandó llamar a doña Ana:

"Para persuadir y reducir a esta su oveja que dejase los torcidos caminos y erradas veredas que llevaba... Y habiendo visto y hablado su ilustrísima (después de haber resistido no poco el acudir a su llamamiento) y hallándola persistente y pertinaz en las cosas de su iluso y errado espíritu, y habiendo yo escrito y vuelto a instar a su ilustrísima (molestado de mi escrúpulo) me diese su parecer y última resolución en este caso, si debía o no delatar de esta mujer, se sirvió su benignidad de responderme con la carta siguiente". ${ }^{57}$

La intolerancia de Alonso de Cristo y el peligro que veía en Ana de Zayas lo llevaron a insistir en que el caso fuera sujeto a una nueva revisión inquisitorial. Este fraile, al tiempo que presionaba al obispo, también se dedicaba a buscar testigos que pudieran impugnar el parecer de Fernández de Santa Cruz en caso de que éste persistiera en sostener la supuesta demencia de doña Ana. ${ }^{58} \mathrm{La}$ carta a la que el denunciante hace referencia en el párrafo anterior fue escrita por el prelado de Puebla en su lugar de retiro, San Miguel del Milagro, un 7 de noviembre de 1694; las palabras que don Manuel dirigió al carmelita Alonso de Cristo decían así:

55 Ibídem, fol. 126. Sabemos, por varias referencias que hace la propia Ana de Zayas y por los testigos llamados a declarar durante las diligencias del proceso, que ella padeció un ataque de furia ocasionado por los pleitos que la acusada tenía con su marido, lo cual fue llamado por la escritora "la locura misteriosa". Los médicos, por su parte, denominaron a tal padecimiento idiopatía de la cabeza.

56 Ibídem, fol. $126 \mathrm{v}$.

57 Ibídem.

58 El 26 de octubre de 1695 fue llamado a declarar el franciscano y calificador del Santo Oficio José Montoro, por él sabemos que un año atrás: "Fray Alonso de Cristo le llevó un escrito para que diese su parecer, en que tiraba a probar que una mujer llamada doña Ana (...) que no estaba loca, sino engañada e ilusa, impugnando en esto un parecer que antecedentemente había dado el dicho señor obispo y los ministros calificadores...” Ibídem, fol. 100. 


\begin{abstract}
"He visto su carta de VR, y aunque finísimamente he puesto la materia que contiene en la presencia de Dios, y como quiera en duda debe preponderar la causa de la religión y daño de ésta a la caridad y daño del particular, me veo obligado a decir que tenga VP por cierto el que esta mujer no es loca, parece que se debe de juntar, que el Tribunal del Santo Oficio, con vista del informe y papeles de vuestro parecer, y de otros, hará juicio. Que en el mío pesa mucho lo que vuestra reverencia me dice, de que se habla ya de esta mujer en la Puebla, y que así recelo su comunicación con otros haga daño grave, porque para causarlo poco importa que sea loca, si es tenida por cuerda. Dios alumbra este Santo Tribunal en materia de fe, de calidad que nadie errará en ponerse en sus manos, pues con tal prudencia atiende a estas causas que mira por las honras de los inocentes, antes de tomar resolución a su averiguación, con que no nos debe detener la caridad del prójimo en perjuicio de la religión, por quien debemos dar la sangre, y ésta puede padecerlo así por lo que VP insinúa como porque el confesor da ascenso a las cosas de esta mujer, según entiendo (y si la creemos) la manda escribir, teniendo su espíritu por bueno. Siendo tan claro lo contrario. VP haga en este negocio, lo que le alumbrare Dios...". ${ }^{59}$
\end{abstract}

La carta del obispo contiene dos mensajes. Uno, obligado, como el mismo Santa Cruz afirma, a dar una supuesta autorización a que Ana de Zayas "parece" debería ser "juntada", no dice denunciada. El otro mensaje cubre a la escritora bajo el protector velo de una locura que sólo el prelado ve. A esto agreguemos el detalle que utiliza el obispo para descargar un poco la culpa de doña Ana, al decir que ella escribía alentada por su confesor, o sea, Alonso Ramos, quien fuera rector del colegio del Espíritu Santo de los jesuitas y autor de la hagiografía de la beata poblana Catalina de San Juan. Lo cual también es relativo, pues Ana de Zayas llevaba tiempo sin ver al jesuita Ramos por hallarse éste enfermo. No nos detendremos por ahora en analizar la relación que el obispo pudo haber tenido con quien fuera rector del colegio del Espíritu Santo de Puebla, al cual, por ser un personaje de gran importancia en la vida de nuestra escritora, abordaremos a profundidad en trabajos posteriores.

Volvamos a la carta que el obispo dirigió al carmelita, asunto que nos ocupa, y veamos cómo el denunciante fue incapaz de leer entre líneas los dobles mensajes del prelado. En su empeño por llevar a Ana de Zayas ante el Santo Oficio, Alonso de Cristo sólo supo mirar en dicho documento la parte donde Fernández de Santa Cruz "apoyaba" que la escritora fuera denunciada. Así, en noviembre de 1694, creyendo el carmelita que tenía las pruebas suficientes contra doña Ana, entrega a la Inquisición de la Nueva España de la ciudad de Puebla la segunda acusación formal contra la mujer

59 Ibídem, fol. 127. 
que el fraile consideraba vehementemente sospechosa de pertenecer a la secta de los herejes alumbrados. A partir de entonces empieza el proceso, es decir, el seguimiento de la denuncia con sus respectivas diligencias judiciales, lo cual ocurría solamente cuando el Santo Oficio consideraba que existían fundamentos sólidos para emprender las averiguaciones.

Entre los diversos testigos que fueron llamados a declarar figuraba el nombre de uno de los personajes más poderosos de la Nueva España: Manuel Fernández de Santa Cruz. El 7 de octubre de 1695 un comisario del Santo Oficio visitó por primera vez al obispo para examinarlo sobre el caso de Ana de Zayas. Pero el enviado del Tribunal no pudo hablar con don Manuel, quien estaba retirado sin recibir a nadie: "por evitar el ruido de parabienes que pretenden darle personas de todos los estados, del cargo de virrey que se dice ser de esta Nueva España" ${ }^{60}$ No sabemos si ésta fue la primera estrategia del prelado para alargar las diligencias del proceso, si efectivamente no podía recibir al comisario, o ambas cosas.

Trece días después, el 20 de octubre, el obispo por fin recibió al comisario del Santo Oficio y lo hizo solamente para releer la carta escrita a Alonso de Cristo sobre el caso de Ana de Zayas, misiva a la que ya hemos aludido. El prelado debía ratificar que dicha carta era suya, cosa que don Manuel no hizo, sino que se limitó a pedirle al representante inquisitorial que regresara al día siguiente a escribir la declaración. ${ }^{61}$ Así, el 21 de octubre, listo para declarar, cuando fue preguntado si era suya la carta escrita a Alonso de Cristo, Fernández de Santa Cruz sacó el recurso con el que libraría por segunda $v^{62} z^{62}$ a Ana de Zayas:

"Dijo su ilustrísima que la firma de dicha carta es suya, y que dicha carta es copia de otra que hizo trasladar a un paje su Sa. Iltma. Y que en cuanto a su contenido, habiéndola leído su Sa. Iltma. reconoce que faltó el escribiente en ajustarse al original, porque a donde puso, tenga $V P$ : está en el original, que teniendo $V P{ }^{63}$ porque hace distinto sentido y contrario al dictamen que siempre ha tenido su Sa. Ilustrísima de la mujer acerca de quien escribió a dicho padre; porque la ha tenido y tiene por loca. Porque esta última vez que le habló, habrá tiempo de tres meses, con ánimo de recogerla (...) le dijo tales despropósitos que hizo y se confirmó en el dictamen de que dicha mujer tenía lúcidos. Porque no hablándola en punto de confesión y de espíritu habla muy en juicio, y que nadie la conocerá por enferma, y que sabe su Sa. Iltma.

60 Ibídem, fol. 83.

61 Ibídem, fol. 107.

62 Y hasta donde sabemos de forma definitiva, por quedar el caso inconcluso sin que el Santo Oficio declarara culpable a la acusada.

63 Subrayado en el original. 
que padeció este achaque de locura habiendo estado atada, por la furia que en una ocasión tuvo. Y que por escrito siempre ha dicho esto mismo su Sa. Iltma. y con los que ha hablado sobre esta materia, y para que conste en este mismo dictamen tuvo, en la carta que se le ha mostrado, exhibe el original, y esto responde su Sa. Iltma. Pero no obstante esto que lleva dicho su Iltma. y el dictamen que tiene explicado, se sujeta a lo que el Sto. Tribunal con vista de autos juzgare por más cierto". ${ }^{64}$

Escrita de su puño y letra, la supuesta carta original que presentó el prelado al comisario en su visita del 21 de octubre tenía una modificación primordial en la frase: "que teniendo VP por cierto el que esta mujer no es loca". Como hemos visto en su propia argumentación, según el obispo, el gerundio de tener marca la diferencia con "tenga VP por cierto el que esta mujer no es loca”. ¿Cuándo fue escrita esta corrección? Quizá después que Manuel Fernández de Santa Cruz pidiera al enviado inquisitorial regresar al siguiente día, es decir, entre el 20 y 21 de octubre de 1695 .

Don Manuel dijo la verdad cuando declaró que meses antes a la visita del comisario inquisitorial había hablado con Ana de Zayas "con ánimo de recogerla". Lo que no sabemos es si el obispo mintió al afirmar que la consideraba loca, locura peculiar, porque sólo la percibía él hablando con la acusada en punto de confesión. El resto de los testigos, los médicos y el denunciante afirmaron que la escritora estaba en perfecto estado mental.

Un detalle más del obispo: se negó a jurar su declaración, como refiere el confundido comisario: "Estuve con el dicho Señor Obispo, y habiéndole besado la mano, le di el referido recado, y habiéndolo oído, me respondió su Sa. Iltma: "vaya VM, y traiga amplia la ratificación y la firmaré cuando VM quisiere". A que le repliqué: "Señor, no puede ser lo que VS me dice, por causa de que han de asistir, según estilo del Santo Oficio y derecho, dos ministros más del Santo Oficio". Y habiéndolo oído me dijo: "no es menester eso, y tráigala VM cuando quisiere que la firmaré". ${ }^{65}$ Ante esta situación, los inquisidores opinaron que el obispo no había sido examinado según las formas del Santo Tribunal y que su testificación sin juramento carecía de valor alguno, por lo que fue necesaria una segunda examinación; ésta se llevó a cabo en diciembre de ese mismo 1695 y Fernández de Santa Cruz ratificó en ella la demencia de doña Ana.

El incidente de Ana de Zayas no fue el único roce que tuvo don Manuel con los miembros del Tribunal; entre otros, podemos citar un docuZayas.

64 AHN, Inquisición, 1731, expediente 34, fols. 66 y 66 v. Proceso Inquisitorial contra Ana de

65 Ibídem, fol. $86 \mathrm{v}$. 
mento con fecha de 16 de junio, año 1694, donde el prelado da cuenta al rey de la tolerancia que ha tenido con el Santo Oficio por evitar competencias de jurisdicción y obviar escándalos. Don Manuel se queja de "No haber en la Nueva España un tribunal que pueda contener al de la Inquisición" ${ }^{66}$ y en varios casos prefería "dejar perder jurisdicción que pasar a competencias infructuosas". ${ }^{67} \mathrm{Al}$ parecer, Fernández de Santa Cruz no estaba a favor de muchos de los movimientos del Tribunal y el interceder para que la escritora no fuera llevada a las cárceles secretas fue una manifestación más de la actitud disconforme que, en general, el prelado sostenía contra el Santo Oficio.

La opinión que mantuvo el obispo sobre el dañado estado mental de la acusada hizo que la balanza se inclinara a favor de ella. El primero de junio de 1697, en una audiencia del Santo Oficio de la Inquisición de México, el inquisidor Juan Gómez de Mier votó a favor del encarcelamiento de la escritora. ${ }^{68}$ El otro inquisidor que revisaba el caso, Juan de Armenta y Ron, dictaminó que la causa fuera suspendida por parecer en los autos que doña Ana estaba falta de juicio. ${ }^{69}$ Después de diversos trámites burocráticos se resolvió que doña Ana de Zayas siguiera en observación, por lo que no fue enviada a las cárceles secretas; hasta 1700, año al que llega el proceso, inconcluso, la escritora continúa escribiendo sin que el Santo Oficio se decidiera a actuar contra ella.

Volvamos a 1695, cuando otros vínculos, además de los inquisitoriales, habían unido a la autora con el prelado: fue él quien se encargó de seguir la demanda que doña Ana puso contra su marido, acusándolo de malos tratos y de estar amancebado con una mestiza. Algunos testigos llamados a declarar en el proceso refieren que el caso fue muy sonado en la ciudad. Alrededor de julio de 1695, es decir en plenas diligencias inquisitoriales contra la escritora, el pleito marital se arregló así: Ana de Zayas,

66 AGI, México 700, s/n.

67 Ibídem.

68 Este inquisidor era tío de Juan Mier y Salinas, quien fuera tesorero de la iglesia poblana, personaje que ocasionó muchos disgustos a Fernández de Santa Cruz alrededor de 1693. Dicho tesorero emprendió una serie de denuncias contra el prelado, aunque finalmente se arrepintió y le pidió perdón por las infamias que divulgó contra el obispo. Es probable que la determinación de encarcelar a Ana de Zayas tomada por este inquisidor tuviera que ver con las rivalidades que el sobrino de dicho ministro inquisitorial tuvo con don Manuel. En otro problema de jurisdicción que Fernández de Santa Cruz tuvo con el Santo Tribunal, el prelado manifiesta abiertamente que la raíz del conflicto se debe a que el inquisidor Mier protegía a su sobrino, el tesorero de la iglesia poblana. Ver AGI, México, 700, s/n. Zayas.

69 AHN, Inquisición, 1731, expediente 34, fol. 126 v. Proceso Inquisitorial contra Ana de 
bajo la manutención de Fernández de Santa Cruz, quedó a salvo de las furias de su marido en la casa de recogidas "Las Granadinas". Por su parte, el violento consorte acabó abandonado y sólo después de que el obispo lo obligara a separarse de su amante.

Manuel Fernández de Santa Cruz aparece frecuentemente en los cuadernillos de doña Ana. En algunos pasajes - como cuando le mandó dejar de escribir por estar poco sana de la cabeza - ella compara la piedad del prelado con la punta de una lanza; en otros momentos la escritora describe escenas como: "El señor obispo soltó la risa de ver que no se me olvida ni una tilde". ${ }^{70}$ Se deja ver que la relación de doña Ana con el prelado era de respeto más no de ciego sometimiento. Ella le dedicó a Fernández de Santa Cruz pequeños relatos, versos en enigmas, reflexiones y los documentos hablan de lo importante que fue la figura del obispo en la vida de la escritora. ¿Llegó doña Ana a saber que la Inquisición seguía un proceso en su contra y que la intervención del prelado de Puebla había sido providencial? Aún no tenemos respuesta para esta pregunta.

En uno de los escasos documentos que se ha conservado de los originales escritos por la mano de Ana de Zayas, podemos leer: "Oh, qué falta me hace este santo prelado". ${ }^{71}$ El escrito marca una fecha, noviembre de 1699; habían pasado ya nueve meses desde aquel febrero en el que don Manuel Fernández de Santa Cruz muriera y su corazón estaba ya en el relicario de cristal donde aún podemos verlo expuesto.

Este trabajo pretende acercarnos, por un lado, a una mujer que interesa por su biografía y obra literaria, y por otro, al famoso obispo de la ciudad de Puebla de los Ángeles, ya conocido por su amistad con sor Juana Inés de la Cruz. Las relaciones entre Ana de Zayas y Manuel Fernández de Santa Cruz, en este caso vinculadas a un proceso inquisitorial, muestran un mundo complejo, pero a la vez humano y comprensivo.

70 Ibídem, fol. $31 \mathrm{v}$.

71 AGN, Inquisición, vol. 692, expediente 2, fol. 290. Proceso Inquisitorial contra Ana de Zayas. 